\title{
加熱処理したアミロメイズVデンプンの人工 消化と幼若ラットに対する成長試験
}

綾 野 雄 幸, 渡 辺 幸 雄, 鈴 木
千葉大学園芸学部農芸化学科

\author{
On the in vitro Digestion of Various Heat-Processed \\ Amylomaize V Starches and on the Growth of \\ Weanling Rats Fed those Starches as a \\ Sole Carbohydrate Source
}

\author{
Yūkō AYANO, Yukio WATANABE, Tōru SUZUKI, Masako YOKOI \\ Department of Agricultural Chemistry, Faculty of Horticulture, \\ Chiba University, Matsudo, Chiba
}

\begin{abstract}
In order to improve the nutritive value of the amylomaize $\mathrm{V}$ starch (amylose contents 49.3\%), it was processed under various conditions. This study was undertaken to estimate the in vitro digestibilities of the processed starches and their effects on growth of weanling rats.

In the in vitro experiment using extract of rat small intestine, the digestibilities of the various alkali or heat-processed amylomaize starches, incubated for 24 hours at $37^{\circ} \mathrm{C}$, were as follows; alkaliprocessed starch $96.8 \%$, raw normal corn starch as a control $92.4 \%$, pregelatinized starch (processed by extruder) $89.6 \%$, autoclaved starch (with $400 \%$ of added water, heated at $120^{\circ} \mathrm{C}$ for $30 \mathrm{~min}$. and freeze dried) $75.2 \%$, steamed starch (with $60 \%$ of added water, heated at $100^{\circ} \mathrm{C}$ for 60 min. and vacuum dried) $71.5 \%$, and raw starch $36.2 \%$.

In the animal experiment, the growth rates of weanling rats fed diets containing the various heatprocessed amylomaize starches at $78 \%$ level of diet, were compared with those of rats fed diet containing either raw amylomaize starch or raw normal corn starch. The pregelatinized starch (processed by extruder) maintained normal growth, but caused slight enlargement of cecum and deteriorated protein digestibility comparing with normal corn starch. The autoclaved starch caused larger cecum, less depot fat and smaller carcass as compared with the pregelatinized starch. Growth indexes, such as body weight gain, feed conversion and protein efficiency ratio of rats fed the autoclaved starch, were not significantly different from those of rats on normal corn starch. The steamed starch showed rather lower digestibility than the autoclaved one. In addition, the former induced slight abnormal growth of the rats. It failed to depress apparent body weight gain of the fed animals, but caused slight decrease of eviscerated carcass weight as well as small depot fat content as compared with the autoclaved one. These results indicated that amylomaize starch could not be improved the nutritive values to be equal with that of raw normal corn starch, even if the former starch was heat-processed at $120^{\circ} \mathrm{C}$ for $30 \mathrm{~min}$.
\end{abstract}

(Received September 29, 1976)

前報1)で，生のアミロメイズVIIテンプンを糖質源とし て幼若ラットに投与した場合，佰常な成长を示さず，下 峲症状を呈し, 消化器官, とくに盲腸において顕著な増 大が锶察された。また, $85 \%$ ×タノールで脱脂洗浄処理 をはどこして投与してる，その成長成績は未処理のデン

$†$ High-Amylose Corn Starch の桨茬学的研究（第 2 報)

Studies on the Nutritive Value of HighAmylose Corn Starch (Part 2)

干 271 千葉県松戸市户定 648
プンの場合と有意差がなかったことを報告した。

このたび, アミロメイズVデンプン（フミロース含量, 49.3\%) を入手できたので, 本実験ではアミロメイズデ ンプンの消化性ならびに栄養効率を向上させる目的で, 種々の条件で加熱処理をほどこした。これら処理デンプ ンについて，その消化性を人工消化試験で調べるととも に, 幼若ラットに投与した場合の成長度, 䀫器重量の変 化, 蓄積脂肪の脂肪酸組成および消化吸収に与える影留 を, 生のアミロメイズデンプンおよび普通トウモロコシ デンプンと対比して調べた。以下，その結果を報告する。 


\section{実 験 方 法}

\section{1. 人工消化試験}

\section{1) 試料の調製}

アミロメイズVデンプンは $85 \%$ メタノールにて洗浄 後エチルエーテルで脱水乾燥したものを用い, 次の処理 法によって試料を調製した。

i ）アルカリ糊化：デンプン 1 に対し， $1 \mathrm{~N}$ 水酸化ナ トリウム液を 10 の割合で加党, 一夜放置後, $0.5 \mathrm{~N}$ 塩 酸にて $\mathrm{pH} 6.0$ に中和し，ただちに凍結乾燥した。

ii）加熱（加水量 $60 \%$ ）:デンプン 1 に対し，水 0.6 の割合で撒水後, 30 メッシュの穊を通して含水度を均一 にし，シャーレに $8 \mathrm{~g}$ ずつとり，濾紙で蓋をして $100^{\circ} \mathrm{C}$ に保ったオートクレーブ内にて 30 分, 60 分蒸煮した。 蒸煮後はただちに真空デシケーターに入れて乾燥した。

iii）加熱（加水量 400\%）：デンプン 1 に対し，水 4 の割合で加水し, 沸とう湯浴中で糊状にしたのち, オ一 トクレーブに入れ， $100^{\circ} \mathrm{C}$ およひ $120^{\circ} \mathrm{C}$ でそれぞれ 30 分，60分処理した。加熱処理したものはただちに凍結乾 燥した。

iv） $\alpha$ 化処理：エクストルーダーにより $\alpha$ 化処理し た。豊年製油侏より提供を受けた。

以上のように調製した各処理デンプンは 100 メッシュ に篩別して，以下の実験に用いた。

2) 人工消化試験法

共栓目盛付試験管に試料デンプンを無水物換算にして $100 \mathrm{mg}$ を科取し，蒸留水 $5 \mathrm{ml}$ を加えてよく分散させ たのち，1/15 M リン酸塩緩衝液（pH 6.8） $5 \mathrm{ml}$, ラッ トの小腸磨砕抽出液 $2 \mathrm{~m} l$ およびトルエン 1 滴を加え,

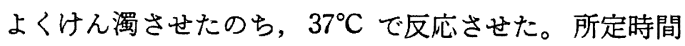
後, 手早く $1 \mathrm{~N}$ 塩酸 $0.4 \mathrm{ml}$ を加えて $20 \mathrm{ml}$ に定容し たのち濾過し, 濾液の一定量について生成還元糖を Willstätter schudel 法 ${ }^{2}$ で定量した。ラットの小腸磨砕 抽出液は次のようにして調製した。まず摘出小腸の内容 物を除き, 生理食塩水で洗浄後, $1 / 15 \mathrm{M}$ リン酸塩緩衝 液（pH 6.8）を加え, ホモジナイズしたのち, 冷アセト ンを加光（最終濃度 $70 \%$ ), 生じた沈㷉物を最初はアセ トン・エチルエーテル等容混合液で, 次にェチルエーテ ルで洗浄・脱水したのち, 60 メッシュ篩別してアセト ンパウダーとした。使用に当っては，1/15 M リン酸塩 緩衝液 ( $\mathrm{pH}$ 6.8) $2 \mathrm{ml}$ につき, アセトンパウダー 50 mg の割合で三角フラスコに入れ，15 分間振とら抽出し たのち, 6,000 r.p.m. にて 10 分間遠沈し, 上澄液をと って酵素液とした。なお，可溶性デンプン $100 \mathrm{mg}$ に， この酵素液 $2 \mathrm{~m} l$ を加え, 試料の人工消化試験と同条件 で 24 時間消化したところ $98.0 \%$ の消化率を示した。 消化率の算出は前報1ににならった。

\section{2. 動物飼育実験}

1) 飼料

Table 1 に示した飼料を用いた。デンプン源として は, 人工消化試験の結果から,アミロメイズデンプンの $120^{\circ} \mathrm{C}-30$ 分加熱（加水量 $400 \%$ ) ・凍結䡎燥デンプン (Diet 2), $100^{\circ} \mathrm{C}-60$ 分蒸煮 (加水量 $60 \%$ ) ・ 風乾デン プン (Diet 3)， $\alpha$ 化処理デンプン (Diet 4) を選び, 対照として生の普通トウモロコシデンプン (Diet 1) お よび生のアミロメイズデンプン（Diet 5) の計 5 種類を 用いた。なお，これらデンプンは次のよらにして調製し た。

i ) $120^{\circ} \mathrm{C}-30$ 分加熱・凍結乾燥 デンプン（以後, $120^{\circ} \mathrm{C}$ 処理アミロメイズデンプンと略記）：アミロメイ ズデンプン $1 \mathrm{~kg}$ に水 $4 l$ を加え, 沸とら湯浴中で糊状 にしてからオートクレーブに移し， $120^{\circ} \mathrm{C}$ にて 30 分間 加熱処理後, ただちに涷結乾燥した。

ii） $100^{\circ} \mathrm{C}$-60 分蒸煮・風乾デンプン (以後, 蒸煮ア ミロメイズデンプンと略記）：アミロメイズデンプン $1 \mathrm{~kg}$ に水 $0.6 l$ を加え，水分が均一になるようによく 㩖汼してからオートクレーブに移し， $100^{\circ} \mathrm{C}$ にて 60 分 間蒸煮後，3〜4 日間風乾した。

iii） $\alpha$ 化処理アミロメイズデンプン：エクストルーダ ーにより $\alpha$ 化処理したもので，豊年製油 K.K.より提 供を受けた。外山ら 33 のグルコアミラーゼ消化法によっ て測定した $\alpha$ 化度は $70.5 \%$ であった。

以上の処理デンプンについて，X線回折を前報1) と同 じ方法で行なった結果を Fig. 1 に示す。ただし，X線 ディフラクトメーターの測定条件のうち, count full scale は $400 \mathrm{c} / \mathrm{s}$ とした。生のアミロメイズデンプンは バレイショデンプンと同様な B 図形を示したが, $120^{\circ} \mathrm{C}$ 処理アミロメイズデンプンおよび $\alpha$ 化処理アミロメイズ デンプンは結晶化度が低く，V図形に近い回折像を示し た。蒸煮アミロメイズデンプンは生デンプンに近い結晶 化度を示し，この程度の処理では $\alpha$ 化されていないこ とを示した。

\section{2）実験動物および飼育方法}

体重 50 60 g のウイスター系雄ラットを日本ラット K.K.より購入し, Table 1 に示した Diet 1 で 1 週間 予備飼育したのち，1 群10匹ずつ 5 群に分け，各実験食 を与えて 28 日間飼育した。なお, 各群の平均体重なら びに予備飼育期間中の体重増加量はほぼ等しくなるよう 配虑した。飼料ならびに水は自由に摄取させ，体重なら びに飼料摂取量は每日定刻に測定した。実験終了日にラ ットは断頭, 放血して殺し, 解剖して肉眼による観察を 行なった。次いで内贜諸器官を摘出し, 重量を測定し た。 
Table 1. Composition of the test diets. (\%)

\begin{tabular}{|c|c|c|c|c|c|}
\hline \multirow{2}{*}{ Companents } & \multicolumn{5}{|c|}{ Diet } \\
\hline & I & II & III & IV & $\mathrm{V}$ \\
\hline Starch & $78^{8)}$ & $78^{b)}$ & $78^{()}$ & $78^{d)}$ & $78^{\mathrm{e})}$ \\
\hline Casein & 15 & 15 & 15 & 15 & 15 \\
\hline Soybean oil & 2 & 2 & 2 & 2 & 2 \\
\hline Salt mixturef) & 4 & 4 & 4 & 4 & 4 \\
\hline Vitamin mixtures) & 1 & 1 & 1 & 1 & 1 \\
\hline Choline chloride & 0.15 & 0.15 & 0.15 & 0.15 & 0.15 \\
\hline Vitamin A & 3,000 (I.U./kg) & 3,000 & 3,000 & 3,000 & 3,000 \\
\hline Vitamin D & $7.5(\mu \mathrm{g} / \mathrm{kg})$ & 7.5 & 7.5 & 7.5 & 7.5 \\
\hline$d l-\alpha$-Tocopherol & $100(\mathrm{mg} / \mathrm{kg})$ & 100 & 100 & 100 & 100 \\
\hline
\end{tabular}

a) Raw normal corn starch.

b) Amylomaize V starch (1)-water (4), autoclaved at $120^{\circ} \mathrm{C}$ for $30 \mathrm{~min}$, , thereafter freeze-dried.

c) Amylomaize V starch (1)-water (0.6), steam-heated at $100^{\circ} \mathrm{C}$ for $60 \mathrm{~min}$., thereafter dried at room temperature.

d) Pregelatinized amylomaize V starch by extruder.

e) Raw amylomaize V starch.

f) The Harper's salt mixture (J. Nutr., 68, 405 (1959)).

g) The vitamin mixture contained. ( $\%$ in the mixture) thiamine, 0.059 ; riboflavin, 0.059 ; niacin, 0.294 ; calcium pantothenate, 0.235 ; pyridoxine- $\mathrm{HCl}, 0.029$; menadione, 0.006 ; biotin, 0.001 , folic acid, 0.002 ; cyanocobalamin, 0.0002 ; myoinositol, 1.176 ; ascorbic acid, 0.588; and lactose, 97.551.

\section{3）蓄皘脂肪の脂肪酸分析}

摘出した後腹壁脂肪の脂肪酸組成は，前報”と同じ方 法で測定した。

4) 見かけの消化吸収率の測定

さきのアミロメイズVデンブンの試験( では, 飼育後

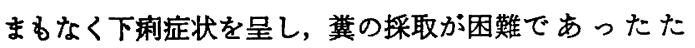
め，今回は実験開始日から8日目までの糞をラットごと に集めた。これを乾燥後，翼中のデンプンおよびたん白 質含量を前報1) と同じ方法で測定し, 見かけの消化吸収 率を求めた。

\section{実 験 結 果}

\section{1. 人工消化試験}

種々の条件で加熱処理をほどこしたアミロメイズデン プイついて, ラット小腸磨碎抽出液を用いて人工消化 試験を行なった結果を Table 2 に示す。

アミロメイズデンプンは, 生では 24 時間消化で 36.2 $\%$ ときわめて低い消化率を示したが，60\% 加水し， $100^{\circ} \mathrm{C}$ で蒸煮するとかなり向上し, 蒸苝時間 30 分では $68.6 \%, 60$ 分では $71.5 \%$ の消化率を示した。また, 乾 燥中の老化を防ぐため涷結乾燥を行なったが, 真空乾 燥とくらべ, 消化率の向上は $1 \sim 3 \%$ とどまった。加 水旦 $400 \%$ で, 加熱温度を $120^{\circ} \mathrm{C}$ にして加熱し, 凍結 乾焻を行なったるのは 24 時間消化で約 $75 \%$ の消化率
を示し，この場合は加熱時間を延長しても消化率は向上 しなかった。アルカリ糊化したアミロメイズデンプンは ほぼ完全に消化されたが，他の加熱処理では，24 時間 消化でくらべると，生の普通トウモロコシデンプンより あかなり消化率が劣った。消化 3 時間扣よび 6 時間目に おいて, 加熱処理したアミロメイズデンプンの消化率 が，普通トウモロコシデンプンのそれにくらべて高いの は，加熱処理によりデンプン粒が膨潤して，消化されや すい形態に变化したためであろう。しかし，24 時間目 の消化率は，生の普通トウモロコシデンプンのそれにく らべてかなり低い值を示したが，これはデンプン粒が膨 潤しても中心部まで十分に糊化されておらず，いまだ強 固なミセルが残存していたためと考兄られる。

\section{2. 動物試験}

1) 成長経過

各群の飼育期間中に括ける成長経過を群平均体重で比 較すると, Fig. 2 のと拈りである。

普通トウモロコシデンプン群と $\alpha$ 化処理フミロメイズ デンプン群は滑らかな成長曲線を示し，順調な成長が見 られたが, $120^{\circ} \mathrm{C}$ 処理アミロメイズデンプン群, 蒸煮了 ミロメイズデンプン群および生アミロメイズデンプン群 では成長がやや不規則であった。この 3 群では第 2 週か ら下淑症状を呈するラットが現われ, 前 2 者では症状す 軽く, その後回復したが, 生フミロメイズデンプン群で 


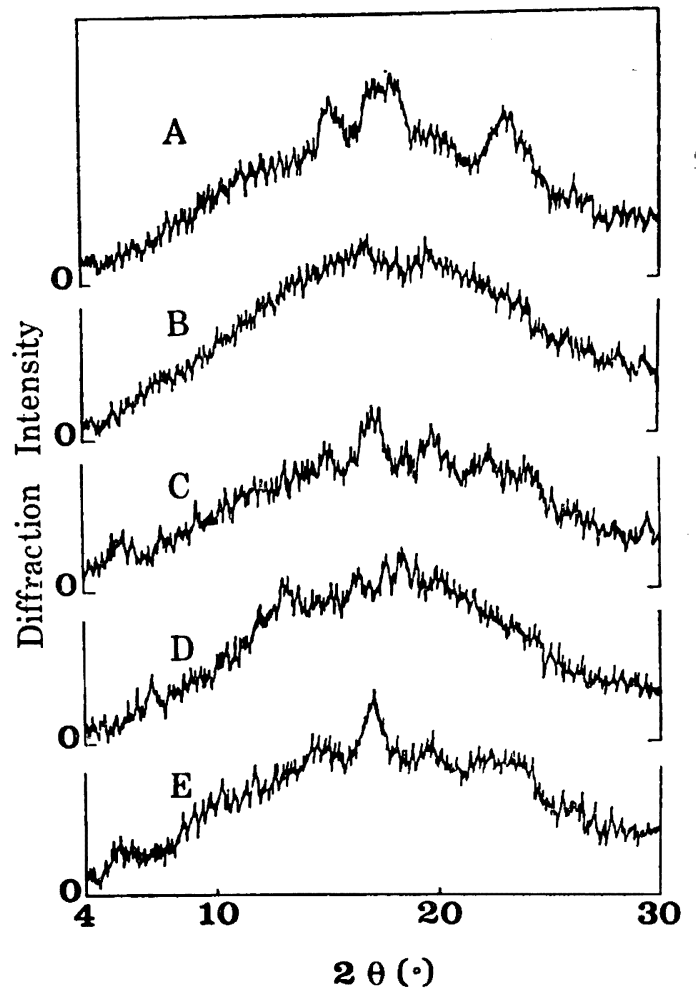

Fig. 1. X-ray diffraction diagrams.

A: Raw normal corn starch, B: Autoclaved $\left(120^{\circ} \mathrm{C}-30 \mathrm{~min}.\right)$ amylomaize $\mathrm{V}$ starch, $\mathrm{C}$ : Steamed $\left(100^{\circ} \mathrm{C}-60 \mathrm{~min}\right.$.) amylomaize V starch, D : Pregelatinized amylomaize V starch, E: Raw amylomaize $\mathrm{V}$ starch.

は10 匹全部が激しい症状を呈してまったく回復せず， 第 4 週には䔬中にデンプン粒が見られた。

次に各群の平均成長結果を, 体重増加率, 飼 料 搨 取

量, 飼料要求率掞よびたん白質効率とともに Table 3 に示す。

体重増加率は, 普通トウモロコシデンプン群と $120^{\circ} \mathrm{C}$ 処理アミロメイズデンプン群および蒸著フミロメイズデ ンプン群の間には有意差が認められなかった。これに対 し, 生アミロメイズデンプン群は普通トウモロコシデン プン群にくらべ, 体重增加率は低く, $\alpha$ 化処理アミロメ イズデンプン群では高い值を示して，ともに $1 \%$ \%危険 率で有意差が認められた。蒸煮アミロメイズデンプン群 の体重増加量は, 試験初期の 10 日目頃までは急激な增 加を示したが，その後の増加は緩やかになり，生アミロ メイズデンプン群と同じであった。他群では 20 日頃ま で順調な増加を示した。

飼料摂取量は, 蒸煮フミロメイズデンプン群および $\alpha$ 化処理アミロメイズデンプン群が多く, 他の 3 群には差 がなかった。この 2 種の飼料には試料調製の際の加熱に より生じた旬いがあり，ラットの嗼好と関俰しているの

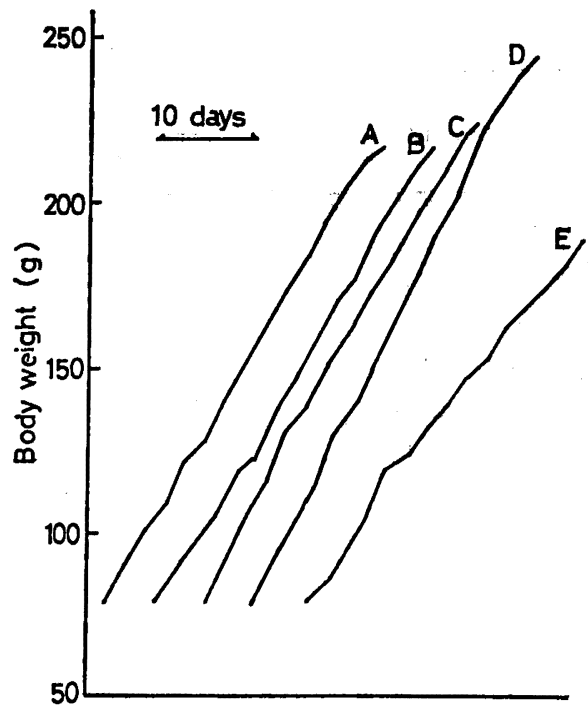

Fig. 2. Growth curves of each dietary group. A : Raw normal corn starch group (Diet 1), B : Autoclaved $\left(120^{\circ} \mathrm{C}-30 \mathrm{~min}.\right)$ amylomaize V starch group (Diet 2), C : Steamed $\left(100^{\circ} \mathrm{C}-60\right.$ min.) amylomaize $\mathrm{V}$ starch group (Diet 3), D: Pregelatinized amylomaize V starch group (Diet 4), E: Raw amylomaize V starch group (Diet 5).

かもしれない。10日目頃から体重増加量が徐々に低下し た蒸煮アミロメイズデンプン群や生アミロメイズデンブ ン群においても，摂取量の減退は見られなかった。

飼料要求率は, 普通トウモロコシデンプン群, $120^{\circ} \mathrm{C}$ 処理アミロメイズデンプン群および蒸煮アミロメイズデ ンプン群の間には有意差は認められなかった。生フミロ メイズデンプン群は他の 4 群にくらべて有意に劣り，と くに激しい下浰症状を呈した最後の 10 日間では飼料要 求率は 15.9 にも達し, 普通トウモロコシデンブン群の 4.3 に比し著るしく高い値を示した。 $\alpha$ 化処理アミロメ イズデンプン群は若干すぐれた值を示したが有意差はな かった。

たん白質効率は, 普通トウモロコシデンプン群, $120^{\circ} \mathrm{C}$ 処理アミロメイズデンプン群および蒸煮アミロメ イズデンプン群の間には有意差は認められなかった。ま た，生アミロメイズデンプン群は有意に低く， $\alpha$ 化观理 アミロメイズデンプン群は他の処理デンプン群に比しす ぐれていた。

以上より，アミロメイズデンプンは加熱処理により幼 若ラットの体重増加, 飼料要求率およびたん白質効虫の 改善が認められ，普通トウモロコシデンプンと見かけ上 ほぼ同様の栄盖効果が得られることが示された。

2 ) 剖検所見ならびに葴器重量

試験終了日に解剖を行ない, 各葴器の変化を肉眼的に 
Table 2. In vitro digestibilities of various heat-processed amylomaize $\mathrm{V}$ starches by extract of rat small intestine.

\begin{tabular}{|c|c|c|c|}
\hline \multirow{2}{*}{ Process } & \multicolumn{3}{|c|}{ Digestibility $(\%)$} \\
\hline & 3 hour & 6 hour & 24 hour \\
\hline None & 11.7 & 18.5 & 36.2 \\
\hline $\begin{array}{l}\text { Solubilization in } \mathrm{N}-\mathrm{NaOH} \text {, neutralization, } \\
\text { followed by freeze-drying }\end{array}$ & 87.1 & 95.0 & 96.8 \\
\hline \multirow{2}{*}{ 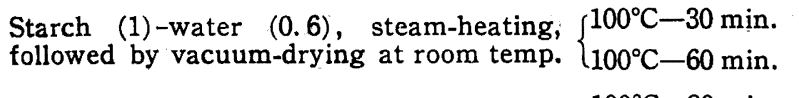 } & 46.4 & 60.7 & 68.6 \\
\hline & 45.1 & 61.8 & 71.5 \\
\hline \multirow{2}{*}{ 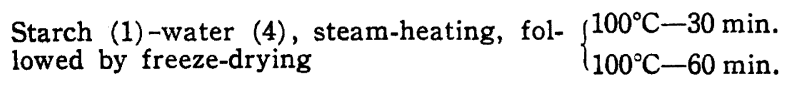 } & 50.6 & 62.3 & 71.5 \\
\hline & 51.3 & 63.4 & 72.7 \\
\hline \multirow{2}{*}{ 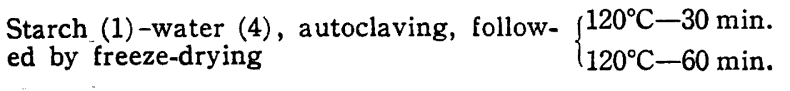 } & 53.7 & 65.9 & 75.2 \\
\hline & 53.0 & 63.5 & 75.1 \\
\hline Pregelatinized by extruder & 50.7 & 67.8 & 89.6 \\
\hline None* & 29.7 & 56.3 & 92.4 \\
\hline
\end{tabular}

* Normal corn starch.

Table 3. Body weight gain, feed conversion and protein efficiency ratio of rats fed on diets containing differently heat processed starches for 28 days.

\pm S.D.

\begin{tabular}{|c|c|c|c|c|c|c|}
\hline \multirow[b]{2}{*}{ Group } & \multicolumn{3}{|c|}{ Body weight } & \multicolumn{3}{|c|}{ Feed consumption } \\
\hline & $\begin{array}{l}\text { Initial } \\
(\mathrm{g})\end{array}$ & $\begin{array}{l}\text { Final } \\
(\mathrm{g})\end{array}$ & Gain ratio & $\begin{array}{c}\text { Feed } \\
\text { intake } \\
(\mathrm{g})\end{array}$ & $\begin{array}{l}\text { Feed } \\
\text { conversion* }\end{array}$ & $\begin{array}{l}\text { Protein } \\
\text { efficiency } \\
\text { ratio** }\end{array}$ \\
\hline Raw normal corn starch & $78.1 \pm 4.8$ & $215.2 \pm 13.8$ & $1.76 \pm 0.21$ & $447.0 \pm 40.2$ & $3.28 \pm 0.21$ & $2.20 \pm 0.17$ \\
\hline $\begin{array}{l}\left.\text { Autoclaved ( } 120^{\circ} \mathrm{C}-30 \mathrm{~min} .\right) \\
\text { amylomaize V starch }\end{array}$ & 78. $1 \pm 5.0$ & $216.4 \pm 15.1$ & $1.78 \pm 0.19$ & $442.0 \pm 31.8$ & $3.21 \pm 0.22$ & $2.24 \pm 0.15$ \\
\hline $\begin{array}{l}\text { Steamed }\left(100^{\circ} \mathrm{C}-60 \mathrm{~min} .\right) \\
\text { amylomaize } \mathrm{V} \text { starch }\end{array}$ & $78.1 \pm 4.8$ & $222.4 \pm 13.7$ & $1.86 \pm 0.22$ & 495. $7 \pm 34.1$ & $3.45 \pm 0.23$ & $2.09 \pm 0.13$ \\
\hline $\begin{array}{l}\text { Pregelatinized amylomaize } \\
\text { V starch }\end{array}$ & $78.1 \pm 5.1$ & $242.0 \pm 19.6$ & $2.10 \pm 0.15$ & $489.6 \pm 41.9$ & $2.99 \pm 0.14$ & $2.50 \pm 0.11$ \\
\hline Raw amylomaize V starch & $78.2 \pm 5.2$ & $184.4 \pm 31.5$ & $1.39 \pm 0.34$ & $468.1 \pm 77.8$ & $4.42 \pm 0.57$ & $1.69 \pm 0.21$ \\
\hline
\end{tabular}

* Feed conversion; feed intake/body weight gain.

** Protein efficiency ratio; body weight gain/protein intake.

観察した。120ㄷ 処理アミロメイズデンプン群および生 アミロメイズデンプン群は, 普通トウモロコシデンプン 群にくらへ脂肪沈着が少なく, 盲腸が増大していた。と くに生フミロメイズデンプン群は脂肪沈着が極端に少な く, 盲腸は他の臟器を横隔膜の下部まで押し上け゚, 腹膑 一杯に拡大していた。これら増大した盲腸の内容物は発 酐桌を放ら，未消化デンブン粒の存在が認められた。

次に, 内臓摘出屠体重および各葴器重量の内葴摘出屠 体比を Table 4 に示す。 $120^{\circ} \mathrm{C}$ 処理アミロメイズデン ブン群および蒸煮アミロメイズデンプン群は, 総体重で は普通トウモロコシデンブン群と差がなかったが, 内蔵 摘出屠体重は小さかった。 $120^{\circ} \mathrm{C}$ 処理了ミロメイズデン ブン群, 蒸煮アミロメイズデンプン群および生アミロメ
イズデンプン群では消化器系（胃・小腸・盲腸・大腸） が普通トウモロコシデンプン群にくらべて大きな値を示 し，とくに盲腸における差は著しかった。またここれら 3 群は後腹壁脂肪が少なく, $120^{\circ} \mathrm{C}$ 処理アミロメイズデ ンプン群および蒸煮アミロメイズデンプン群では, 体重 増加率と飼料摂取量は普通トゥモロコシデンプン群と変 わりなくても脂肪蓄積が少なかったことを示した。

\section{3) 見かけの消化吸収}

試験初期 8 日間における各群のデンプンならびにたん 白質の見かけの消化吸収率を Table 5 に示す。

鿓の排泄量 (乾物量) は, 普通トウモロコシデンプン 群が 1 日平均 $0.31 \mathrm{~g}$ であるのに対し， $120^{\circ} \mathrm{C}$ 処理アミ ロメイズデンプン群はその約 3 倍, 蒸煮アミロメイズデ 
Table 4. Relative weight of organs to eviscerated carcasses.

\pm S.D.

\begin{tabular}{lccccc}
\hline \multicolumn{1}{c}{ Organ } & $\begin{array}{c}\text { Raw } \\
\text { normal } \\
\text { corn starch }\end{array}$ & $\begin{array}{c}\text { Autoclaved } \\
\text { amylomaize } \\
\text { V starch* }\end{array}$ & $\begin{array}{c}\text { Steamed } \\
\text { amylomaize } \\
\text { V starch** }\end{array}$ & $\begin{array}{c}\text { Pregelatinized } \\
\text { amylomaize V } \\
\text { starch }\end{array}$ & $\begin{array}{c}\text { Raw } \\
\text { amylomaize } \\
\text { V starch }\end{array}$ \\
\hline Carcass & $171 \pm 11(\mathrm{~g})$ & $161 \pm 13$ & $159 \pm 11$ & $192 \pm 16$ & $126 \pm 24$ \\
Carcass/Body weight & $79.6 \pm 0.93(\%)$ & $74.3 \pm 1.20$ & $71.6 \pm 1.48$ & $79.1 \pm 1.07$ & $66.9 \pm 2.30$ \\
\hline Thymus & $0.35 \pm 0.09(\%)$ & $0.38 \pm 0.05$ & $0.36 \pm 0.07$ & $0.35 \pm 0.06$ & $0.36 \pm 0.07$ \\
Lung & $0.68 \pm 0.13$ & $0.70 \pm 0.09$ & $0.76 \pm 0.14$ & $0.68 \pm 0.09$ & $0.80 \pm 0.11$ \\
Heart & $0.51 \pm 0.06$ & $0.54 \pm 0.05$ & $0.52 \pm 0.03$ & $0.50 \pm 0.05$ & $0.57 \pm 0.07$ \\
Liver & $5.22 \pm 0.44$ & $5.14 \pm 0.38$ & $5.23 \pm 0.49$ & $5.22 \pm 0.54$ & $5.36 \pm 0.41$ \\
Stomach & $0.50 \pm 0.05$ & $0.60 \pm 0.06$ & $0.58 \pm 0.04$ & $0.56 \pm 0.07$ & $0.68 \pm 0.10$ \\
Small intestine & $1.80 \pm 0.28$ & $2.15 \pm 0.29$ & $2.27 \pm 0.47$ & $1.57 \pm 0.12$ & $3.27 \pm 0.41$ \\
Cecum*** & $1.32 \pm 0.21$ & $7.67 \pm 1.40$ & $11.01 \pm 1.61$ & $2.49 \pm 0.49$ & $16.00 \pm 2.91$ \\
Cecum & $0.44 \pm 0.07$ & $1.46 \pm 0.40$ & $1.58 \pm 0.24$ & $0.60 \pm 0.13$ & $2.26 \pm 0.54$ \\
Large intestine & $0.27 \pm 0.06$ & $0.38 \pm 0.06$ & $0.43 \pm 0.11$ & $0.28 \pm 0.06$ & $0.47 \pm 0.10$ \\
Spleen & $0.28 \pm 0.03$ & $0.30 \pm 0.04$ & $0.31 \pm 0.05$ & $0.30 \pm 0.04$ & $0.34 \pm 0.06$ \\
Kidneys & $0.97 \pm 0.07$ & $1.05 \pm 0.08$ & $1.19 \pm 0.18$ & $1.03 \pm 0.05$ & $1.41 \pm 0.27$ \\
Adrenals & $0.0189 \pm 0.0088$ & $0.0276 \pm 0.0074$ & $0.0248 \pm 0.0062$ & $0.0229 \pm 0.0054$ & $0.0323 \pm 0.0085$ \\
Testicles & $1.47 \pm 0.20$ & $1.61 \pm 0.21$ & $1.64 \pm 0.21$ & $1.42 \pm 0.15$ & $2.00 \pm 0.22$ \\
Retroperitoneal fat & $1.26 \pm 0.46$ & $0.89 \pm 0.35$ & $0.80 \pm 0.28$ & $1.19 \pm 0.31$ & $0.36 \pm 0.14$ \\
\hline \hline
\end{tabular}

* Autoclaved at $120^{\circ} \mathrm{C}$ for $30 \mathrm{~min}$.

** Steamed at $100^{\circ} \mathrm{C}$ for $60 \mathrm{~min}$.

*** With contents.

Table 5. Digestibility of starch and protein for first 8 days on experimental diets.

\pm S.D.

\begin{tabular}{|c|c|c|c|c|c|c|c|c|c|}
\hline \multirow[b]{2}{*}{ Group } & \multicolumn{2}{|c|}{ Content } & \multirow[b]{2}{*}{$\begin{array}{l}\text { Weight } \\
\text { of } \\
\text { feces* } \\
(\mathrm{g})\end{array}$} & \multicolumn{3}{|c|}{ Starch } & \multicolumn{3}{|c|}{ Protein } \\
\hline & $\begin{array}{l}\text { Starch } \\
(\%)\end{array}$ & $\begin{array}{l}\text { Protein } \\
(\%)\end{array}$ & & $\begin{array}{l}\text { Daily } \\
\text { intake } \\
(\mathrm{g})\end{array}$ & $\begin{array}{l}\text { Daily } \\
\text { output } \\
(\mathrm{g})\end{array}$ & $\begin{array}{l}\text { Apparent } \\
\text { digesti- } \\
\text { bility } \\
(\%)\end{array}$ & $\begin{array}{c}\text { Daily } \\
\text { intake } \\
(\mathrm{g})\end{array}$ & $\begin{array}{l}\text { Daily } \\
\text { output } \\
\text { (mg) }\end{array}$ & $\begin{array}{c}\text { Apparent } \\
\text { digesti- } \\
\text { bility } \\
(\%)\end{array}$ \\
\hline $\begin{array}{l}\text { Raw normal corn } \\
\text { starch }\end{array}$ & 63.85 & 14.24 & $\begin{array}{l}0.31 \\
\pm 0.06\end{array}$ & $\begin{array}{l}8.78 \\
\pm 1.04\end{array}$ & $\begin{array}{l}0.03 \\
\pm 0.00\end{array}$ & $\begin{array}{l}99.7 \\
\pm 0.06\end{array}$ & $\begin{array}{l}1.96 \\
\pm 0.23\end{array}$ & $\begin{array}{l}122.2 \\
\pm 22.6\end{array}$ & $\begin{array}{l}93.8 \\
\pm 0.92\end{array}$ \\
\hline $\begin{array}{l}\text { Autoclaved }\left(120^{\circ} \mathrm{C}\right. \\
-30 \text { min. }) \text { amylo- } \\
\text { maize V starch }\end{array}$ & 64.76 & 13.96 & $\begin{array}{l}1.07 \\
\pm 0.32\end{array}$ & $\begin{array}{l}7.88 \\
\pm 0.79\end{array}$ & $\begin{array}{l}0.49 \\
\pm 0.21\end{array}$ & $\begin{array}{l}94.0 \\
\pm 2.06\end{array}$ & $\begin{array}{l}1.70 \\
\pm 0.17\end{array}$ & $\begin{array}{l}249.7 \\
\pm 52.5\end{array}$ & $\begin{array}{l}85.9 \\
\pm 2.99\end{array}$ \\
\hline $\begin{array}{l}\text { Steamed }\left(100^{\circ} \mathrm{C}-\right. \\
60 \text { min. }) \\
\text { maize V starch }\end{array}$ & 63.75 & 13.91 & $\begin{array}{l}2.48 \\
\pm 0.38\end{array}$ & $\begin{array}{l}9.82 \\
\pm 0.87\end{array}$ & $\begin{array}{l}1.58 \\
\pm 0.32\end{array}$ & $\begin{array}{l}83.9 \\
\pm 3.20\end{array}$ & $\begin{array}{l}2.14 \\
\pm 0.19\end{array}$ & $\begin{array}{l}338.7 \\
\pm 32.8\end{array}$ & $\begin{array}{l}84.1 \\
\pm 1.80\end{array}$ \\
\hline $\begin{array}{l}\text { Pregelatinized amy- } \\
\text { lomaize V starch }\end{array}$ & 65.07 & 13.42 & $\begin{array}{l}0.56 \\
\pm 0.10\end{array}$ & $\begin{array}{l}9.48 \\
\pm 1.03\end{array}$ & $\begin{array}{l}0.08 \\
\pm 0.03\end{array}$ & $\begin{array}{l}99.2 \\
\pm 0.18\end{array}$ & $\begin{array}{l}1.95 \\
\pm 0.22\end{array}$ & $\begin{array}{l}211.9 \\
\pm 32.8\end{array}$ & $\begin{array}{l}89.2 \\
\pm 0.83\end{array}$ \\
\hline $\begin{array}{l}\text { Raw amylomaize V } \\
\text { starch }\end{array}$ & 66.61 & 13.59 & $\begin{array}{l}3.53 \\
\pm 0.70\end{array}$ & $\begin{array}{l}8.89 \\
\pm 1.38\end{array}$ & $\begin{array}{l}2.54 \\
\pm 0.55\end{array}$ & $\begin{array}{l}71.6 \\
\pm 3.10\end{array}$ & $\begin{array}{l}1.83 \\
\pm 0.27\end{array}$ & $\begin{array}{l}308.7 \\
\pm 65.6\end{array}$ & $\begin{array}{l}83.1 \\
\pm 2.15\end{array}$ \\
\hline
\end{tabular}

* Mean value of daily excrement per rat. 
Table 6. Weight and fatty acid composition of retroperitoneal depot fat.

\pm S.D.

\begin{tabular}{|c|c|c|c|c|c|c|c|c|}
\hline \multirow{2}{*}{ Group } & \multirow{2}{*}{$\begin{array}{l}\text { Weight } \\
(\mathrm{g})\end{array}$} & \multicolumn{7}{|c|}{ Fatty acid composition $(\%)$} \\
\hline & & $\mathrm{C}_{14}$ & $\mathrm{C}_{16}$ & $C_{16: 1}$ & $\mathrm{C}_{18}$ & $\mathrm{C}_{18: 1}$ & $\mathrm{C}_{18: 2}$ & $\mathrm{C}_{18: 3}$ \\
\hline Raw normal corn starch & $\begin{array}{l}2.17 \\
\pm 0.88\end{array}$ & $\begin{array}{l}2.2 \\
\pm 0.21\end{array}$ & $\begin{array}{l}32.4 \\
\pm 1.65\end{array}$ & $\begin{array}{l}12.6 \\
\pm 1.21\end{array}$ & $\begin{array}{l}2.5 \\
\pm 0.46\end{array}$ & $\begin{array}{l}41.6 \\
\pm 2.12\end{array}$ & $\begin{array}{l}7.6 \\
\pm 1.59\end{array}$ & $\begin{array}{l}1.1 \\
\pm 0.27\end{array}$ \\
\hline $\begin{array}{l}\text { Autoclaved }\left(120^{\circ} \mathrm{C}-30\right. \\
\text { min.) amylomaize V V } \\
\text { starch }\end{array}$ & $\begin{array}{l}1.46 \\
\pm 0.68\end{array}$ & $\begin{array}{l}2.3 \\
\pm 0.29\end{array}$ & $\begin{array}{l}31.6 \\
\pm 1.53\end{array}$ & $\begin{array}{l}11.6 \\
\pm 1.23\end{array}$ & $\begin{array}{l}3.5 \\
\pm 0.59\end{array}$ & $\begin{array}{l}41.9 \\
\pm 1.68\end{array}$ & $\begin{array}{l}8.2 \\
\pm 1.70\end{array}$ & $\begin{array}{l}0.8 \\
\pm 0.16\end{array}$ \\
\hline $\begin{array}{l}\text { Steamed }\left(100^{\circ} \mathrm{C}-60 \mathrm{~min} .\right) \\
\text { amylomaize V starch }\end{array}$ & $\begin{array}{l}1.30 \\
\pm 0.54\end{array}$ & $\begin{array}{l}2.0 \\
\pm 0.18\end{array}$ & $\begin{array}{l}30.8 \\
\pm 1.58\end{array}$ & $\begin{array}{l}10.3 \\
\pm 1.77\end{array}$ & $\begin{array}{l}3.7 \\
\pm 0.75\end{array}$ & $\begin{array}{l}43.2 \\
\pm 2.98\end{array}$ & $\begin{array}{l}8.6 \\
\pm 1.02\end{array}$ & $\begin{array}{l}1.4 \\
\pm 0.27\end{array}$ \\
\hline $\begin{array}{l}\text { Pregelatinized amylo- } \\
\text { maize V starch }\end{array}$ & $\begin{array}{l}2.30 \\
\pm 0.79\end{array}$ & $\begin{array}{l}2.2 \\
\pm 0.24\end{array}$ & $\begin{array}{l}32.5 \\
\pm 1.96\end{array}$ & $\begin{array}{l}12.7 \\
\pm 1.09\end{array}$ & $\begin{array}{l}3.0 \\
\pm 0.45\end{array}$ & $\begin{array}{l}40.8 \\
\pm 1.91\end{array}$ & $\begin{array}{l}7.8 \\
\pm 0.87\end{array}$ & $\begin{array}{l}1.0 \\
\pm 0.39\end{array}$ \\
\hline Raw amylomaize V starch & $\begin{array}{l}0.46 \\
\pm 0.28\end{array}$ & $\begin{array}{l}2.1 \\
\pm 0.18\end{array}$ & $\begin{array}{l}30.2 \\
\pm 1.76\end{array}$ & $\begin{array}{l}8.6 \\
\pm 2.04\end{array}$ & $\begin{array}{l}4.9 \\
\pm 1.07\end{array}$ & $\begin{array}{l}43.4 \\
\pm 2.78\end{array}$ & $\begin{array}{l}9.5 \\
\pm 1.17\end{array}$ & $\begin{array}{l}1.2 \\
\pm 0.16\end{array}$ \\
\hline
\end{tabular}

ンプン群は約 8 倍, 生フミロメイズデンプン群は約 11 倍 と多くなっており，普通トウモロコシデンプン群では䨢 中のデンブン量が $10 \%$ 以下であるのに対し, 生フミロ メイズデンプン群では $72 \%$ ああることから，この差は 不消化デンプンに由来するすのが大部分であると考えら れる。また, Sandstedt ら゙は生のアミロメイズデンプ ンを投与したラットの蕒中には，完全な形のデンプン粒 が存在することを報告している。

デンプンの消化吸収率は, 普通トウモロコシデンプン 群と $\alpha$ 化処理アミロメイズデンプン群はいずれも $99 \%$ 以上を示して最もすぐれ，両者の間には有意差が認めら れなかった。他の群の間には $1 \%$ \%危険率で有意差がす へて認められ，その差もきわめて大きかった。 $120^{\circ} \mathrm{C}$ 処 理フミロメイズデンプン群と蒸煮フミロメイズデンプン 群は, 飼料要求率, たん白質効率では差が認められなか ったが、デンプンの消化吸収率では, 前者が $94.0 \%$, 後 者か $83.9 \%$ を示し, $120^{\circ} \mathrm{C}-30$ 分加熱処理の効果が蒸 煮処理よりも大きいことが示された。アミロメイズデン プンはその遗伝子形により消化性の異なることが知られ ているがい，本実験での生フミロメイズデンプン群の消 化财収率は 71.6\%で, Borchers ${ }^{5)}$ の報告とほぼ同じ値 を示した。

たん白質の消化吸収率は，デンプンの消化吸収率と異 なり, 普通トウモロコシデンプン群と $\alpha$ 化処理アミロ メイズデンプン群との間には1\%の危険率で有意差が認 められ, 前者が $93.8 \%$ の消化率を示したのに対し, 後 者は $89.2 \%$ であった。アミロメイズデンプン投与の各 群の間では, 蒸煮アミロメイズデンプン群と生フミロメ イズデンプン群の間に有意差がないほかは，すべての群 の間に有意差が認められ、ここに括いても $120^{\circ} \mathrm{C}-30$ 分 加熱処理の効果が蒸著処理よりも大きいことが示され た。
4 ）後腹壁脂肪の脂肪酸組成

後腹壁脂肪の重量ならびに脂肪酸組成を Table 6 に 示す。

各群を通してみると, パルミチン酸およびパルミトレ イン酸は後腹壁脂肪量の多い群に増加する傾向を示し, ステアリン酸およびリノール酸は後腹壁脂肪量が少ない 群に増加する傾向を示した。ミリスチン酸, オレイン酸 およびリノレン酸は差が認められなかった。実験に用い た飼料はどれも脂肪含量 $2 \%$, 必須脂肪酸が不足しな い程度の低脂肪食であるから，体脂肪の多くはデンプン より合成されたと考えられる。体脂肪の多少を示す指標 となる後腹壁脂肪量が少ない $120^{\circ} \mathrm{C}$ 処理フミロメイズデ ンプン群, 蒸煮フミロメイズデンプン群および生フミロ メイズデンプン群では, 必須脂肪酸であるリノール酸の 割合が高く, 生合成脂肪酸の約 $50 \%$ 以上を占める いわれるパルミチン酸の割合が低かった。この事実は, これら 3 群のデンプン消化吸収率が低いことと一致し て, 体内での脂肪合成が進まなかったことを示してい る。 $120^{\circ} \mathrm{C}$ 処理了ミロメイズデンプン群は蒸煮アミロメ イズデンプン群よりる, 脂肪酸組成が普通トゥモロコシ デンプン群に近く, 加熱処理効果によるデンプンの消化 吸収量の增大を塞付けている。 $\alpha$ 化処理了ミロメイズデ ンプン群は後腹壁脂肪量, 脂肪酸組成ともに普通トウモ ロコシデンプン群と差が認められなかった。

\section{考察}

アミロメイズVデンプンは, 生のままではさきに報 告1)したアミロメイズVIデンプンの場合と同様, 消化性 が非常に劣ったが，加熱処理をほとこすことにより，そ の消化性は向上した。本実験に用いた $100^{\circ} \mathrm{C}-60$ 分蒸煮 (60\% 加水) デンプンや $120^{\circ} \mathrm{C}-30$ 分加熱 $(400 \%$ 加 水）デンプンは，人工消化試験では消化率が生のるのに 
くらべ，倍以上に向上した。しかし， $\alpha$ 化処理したもの や普通トゥモロコシデンプンよりは劣った。両加熱デン プンを幼若ラットに投与した成長試験では，見かけの成 長面は普通トウモロコシデンプンと大差ない結果を得た が，デンプンの消化吸収率は低く，脂肪の沈着が悪く， 軽い下浰症状や盲腸の增大を示した。

以上の現象から，フミロメイズVデンプンは，この程 度の加熱処理では粒構造がいまだ壊れずに相当残ってお。 り, ラットの盲腸増大や下痢症状は, この種デンプンの 難消化性による影響と推察される。したがって，この種 デンプンは普通デンプンと同しような加熱調 理だけで は，糖質源として利用し難いと考えられる。しかし，こ の種デンプンの難消化性, 低栄養効率を考㦄して, 低力 ロリー食品の糖質源素材への利用を考える場 合には, $120^{\circ} \mathrm{C}-30$ 分の加熱処理が注目される。この処理デンプ ンの幼若ラットに対する成長試験では，見かけの成長面 は普通トウモロコシデンプン群と美が認められなかった が，体脂肪の多少を示す目安となる後腹壁脂肪量は普通 トウモロコシデンプン群の約 $67 \%$ といら結果が得られ た。たた，この場合, 盲腸の増大が問題であり,この点 については糖質源中に怙けるこの種デンプンの配合比率 を調節することにより，解決できるのではないかと考え られ，今後の研究にまちたい。

$\alpha$ 化処理アミロメイズデンプンが十分に $\alpha$ 化されて いることは, 人工消化試験の結果からも推察され, 幼若 ラットの成長試験では普通トゥモロコシデンプン群より すぐれた成長を示し, 盲腸が少し増大したほかは普通卜 ウモロコシデンプン群と変わるところがなかった。

\section{要旨}

アミロメイズVデンプン (アミロース含量 49.3\%) の消化性ならびに栄塊効率を向上させるために, 種々の 加熱条件で処理をほどこしたのち, 人工消化試験ならび に幼若ラットに投与し, 成長に及ぽす影敏を生のアミロ メイズデンプン就よ゙普通トゥモロコシデンプンと対比 して調べた。

1) 加熱処理アミロメイズデンプンのラット小腸磨碎 抽出液による $37^{\circ} \mathrm{C}, 24$ 時間の人工消化試験で，その消
化率は $\alpha$ 化処理デンプン（土クストルーダーによる） $89.6 \%, 120^{\circ} \mathrm{C}-30$ 分加熱 (加水量 $400 \%$ ) デンブン $75.2 \%, 100^{\circ} \mathrm{C}-60$ 分蒸煮（加水量 $60 \%$ ） デンプン 71.5 \%を示し, 生アミロメイズデンプン $36.2 \%$ に比し, 消 化率の向上は著しかった。な拉, 普通トウモロコシデン プンの消化率は $92.4 \%$ であった。

2 ）動物試験では， $\alpha$ 化処理デンプン群は順調な成長 を示したが，普通トウモロコシデンプン群に比し，盲腸 が少し増大し，たん白質の消化吸収率が少し劣った。 $120^{\circ} \mathrm{C}-30$ 分加熱デンプン群は成長がやや不規則で，体 重増加率, 飼料要求率およびたん白質効率は普通卜ウモ ロコシデンプン群と有意差がなかった。 $\alpha$ 化処理デンフ ン群とくらべると，内臓摘出屠体比は小さく，盲腸はい くらか增大し，デンプンおよびたん白質の消化吸収率は わずかに劣り，体脂肪の蓄積量も少なかった。 $100^{\circ} \mathrm{C}$ 60分蒸煮デンプン群も成長がやや不規則で，見かけの成 長度は $120^{\circ} \mathrm{C}-30$ 分加熱デンプン群と有意差がなかった か，内臓摘出屠体比，デンプンの消化吸収率，体脂肪の 蓄積量では劣った。

3) アミロメイズVデンプンは加熱処理により，その 栄養効率は向上したが, $120^{\circ} \mathrm{C}-30$ 分処理しても生の普 通トウモロコシデンプンの栄養効率には到底及ばなかっ た。

終わりに，本実験を行ならにあたり，試料デンブンを 提供くださった豊年製油株式会社に深謝します。本報の 大要は日本栄養・食糧学会第 28 回大会 (1974 年 5 月) に打いて発表した。

\section{文献}

1）綾野雄幸, 古橋樹雄, 渡辺幸雄, 鉿木 徽, 高居 百合子, 岩尾裕之: 栄養之食糧, 30, 113 (1977)

2）满田久輝 : 実験栄羡化学, P. 165 (1961), いずみ 書房 (京都)

3）外山忠男, 檜作 進, 二国二郎 : 㴬粉工誌, 13, 69 (1966)

4) Sandstedt, R.M., Strahan, D., Ueda, S. and Abbott, R.C. : Cereal Chem., 39, 123 (1962)

5) Borchers, R. : Cereal Chem., 39, 145 (1962)

6) Rehold, A.E. and Cahill, J.R.: Adipose Tissue, American Physiological Society, p. 399 (1965)

(昭和 51 年 9 月 29 日受理) 